\title{
Assessing the effectiveness of yoga, Tai Chi and aerobics on the fatigue of multiple sclerosis patients
}

\author{
Zorina Alina STROE ${ }^{1}$, Silviu DOCU AXELERAD ${ }^{2}$, Alexandru Floris STUPARU ${ }^{3}$, Daniel \\ DOCU AXELERAD 4
}

\begin{abstract}
Introduction: Multiple sclerosis is a chronic, autoimmune, debilitating disease that affects the central nervous system, and the affected population is predominantly young. Over time, patients with multiple sclerosis end up developing an inability to perform physical activities, even the most basic, innate, such as walking or even coordination.

Purpose: Physical recovery of patients with multiple sclerosis, in fact, recovery from fatigue is the main goal of this study, because fatigue is a prevalent factor among these individuals, producing negative effects on the physical, mental, but also on the emotional status.

Method: We analyzed, from the point of view of the Modified Fatigue Impact Scale Test - 5-Item Version (MFIS-5), the level of fatigue in a group of 75 patients with multiple sclerosis, before and after a period of one month, where patients were divide $d$ into three groups and every group practiced one of the following sports activities: yoga, Tai Chi and aerobics.

Results: The effectiveness of each sport was analyzed, from the point of view of the level of fatigue, having as reference the first measurement performed before the beginning of the sports programs. A significant difference in effectiveness was found in the group of patients with multiple sclerosis who used yoga.

Conclusion: Our results provided evidence for the association of exercise methods that can affect beneficially the level of fatigue in multiple sclerosis patients, the most effective one being yoga.

Key words: multiple sclerosis, fatigue, yoga, Tai Chi, aerobics.
\end{abstract}

\section{Rezumat}

Introducere: Scleroza multiplă este o boală cronică, autoimună, debilitantă, care afectează sistemul nervos central, iar populația afectată este preponderent constituită din tineri. În timp, pacienții cu scleroză multiplă ajung să dezvolte incapacitatea de a își desfașura activitățile fizice, chiar și cele de bază, înnăscute; au tulburări de mers și coordonare.

Scop: Recuperarea fizică a pacienților cu scleroză multiplă, în fapt, vindecarea fatigabilității constituie principalul scop al acestui studiu, deoarece fatigabilitatea este un factor prevalent printre acești indivizi, producând efecte negative pe plan fizic, mental, dar și emoțional.

Metode. Am analizat cu ajutorul testului Modified Fatigue Impact Scale Test - 5-Item Version (MFIS-5), nivelul de fatigabilitate a unui lot de 75 de pacienți cu scleroză multiplă, înainte și după o lună de activități fizice. Pacienții au fost împărțiți în trei grupuri și fiecare grup, în parte, a practicat una din activitățile sportive: yoga, Tai Chi și aerobic

Rezultate: A fost analizată efectivitatea fiecărui tip de activitate sportivă, din punctul de vedere al nivelului fatigabilității având ca reper prima măsuratoare efectuată înaintea începerii programelor sportive. A fost constatată o diferență semnificativă în rândul efectivității pentru grupul de pacienți cu scleroză multiplă care a folosit yoga.

Concluzie: Rezultatele obținute de noi constituie un argument asupra beneficiului anumitor activități fizice asupra fatigabilității la pacienții cu scleroză mutiplă, cea mai eficientă fiind yoga.

Cuvinte cheie: scleroză multiplă, fatigabilitate, yoga, Tai Chi, aerobic.

\footnotetext{
1 Assistant Professor, PhD student, Neurology Department, Faculty of General Medicine, “Ovidius” University, Constanta, Romania.

2 Student at the Faculty of General Medicine, Vasile Goldiș Western University of Arad, Romania.

${ }^{3}$ Medical doctor at Sibiu County Hospital, Sibiu, Romania.

${ }^{4}$ Professor, PhD, Ovidius University, Faculty of Physical Education and Sport, Constanta, Romania; email: docuaxi@yahoo.com
} 


\section{Introduction}

Multiple sclerosis is a progressive inflammatory and neurodegenerative disease of the central nervous system, in which apoptosis of oligodendrocytes is the initial paradigm, with the secondary recruitment of the immune system, mainly microglia and lymphocytes that affect axons and myelin and, in the progressive stages, over time, it disappears. The disease can have a natural evolution in various stages; therefore it can be found as an autopsy finding, but in most of the cases it evolves towards the status of atrophy of the brain and spinal cord. Multiple sclerosis is the principal cause of the highest degree of neurological disability in young adults [1].

Multiple sclerosis symptoms include: numbness, tingling, loss of muscle strength, paralysis, impairments in balance and walk, and difficulties with both coordination and dexterity. Spasm and stiffness may be present, also bladder/bowel problems may appear, among speech difficulties and overall mental and physical tension. On the other hand, the following emotional disturbances are present: depression, anxiety, mood swings, frustration and fears. Also, the tiredness is a debilitating problem regarding this disease [1].

The concept of multiple sclerosis has undergone changes, as the patients experience an important degree of complexity of symptoms and signs. This fact requires general, but also individual strategies, since each patient is individual and is not equal to the other. Furthermore, the current concept, involves a group of treatment, consisting of: neurologists, neuropsychologists, physical therapists, rehabilitation technicians, physical education graduates, staff specialized in nursing, social workers, speech therapists, among others [2]. People with multiple sclerosis should have a normal and active life inside of the limitations that their symptoms impose on them. This means that sports activity for multiple sclerosis patients is more advisable than in the rest of the population. The recommendations for the patients imply them to be productive and work; although it is understandable that the symptoms and problems can make it difficult and it takes more time and energy, it will always be better to engage in physical activities. People with multiple sclerosis feel happier and more satisfied when they lead a normal life and carry out the activities they enjoy [2].

Fatigue represents a prevalent symptom experienced by the majority of multiple sclerosis patients. The symptom of fatigue includes energy loss, sleepiness, and inability to sustain activity. Therefore, fatigue appears to increase cognitive complaints and it is correlated with a decrease in self-effectiveness. In literature, the fatigue has been shown to be reducible with physical activity [2].

A generally accepted idea regarding multiple sclerosis patients is to maintain the best shape possible, both physically and mentally, in order to face any challenge that the disease might present [3]. Fatigue is a constant problem for multiple sclerosis patients and the advice is to exercise when it is less intense, to schedule the exercise routine in periods with breaks, or to design the type and model of exercise that can still be performed. The programs of group exercise tend to motivate people to participate regularly and, in addition to that, they carry a very pleasant social aspect. Because fatigue is the major problem for patients with multiple sclerosis, it is important to maintain a reasonable balance between activities [4].

\section{Yoga}

Practicing yoga can provide the tools to help patients with multiple sclerosis cope with the disease and manage everyday tasks in a more beneficial way [5]. The relaxing benefits of yoga may also help manage the frequent challenges of multiple sclerosis, such as fatigue, that is often debilitating, affecting the patients from the physical and mental angles. Studies on the effect of yoga on multiple sclerosis patients show improvement specifically in the fatigue experienced almost universally by individuals with multiple sclerosis $[6$, 7].

\section{Tai Chi}

Tai Chi is a martial art of Chinese origin that is based on the development of inner energy by practicing predetermined movements softly. It is an intense and complete practice, beneficial at any age. Tai Chi thus falls within a long tradition in Chinese therapies and exercises to improve the individuals' quality of life. Tai Chi exercises connect the body, 
mind and spirit, which makes it the art of action. It is by action and movement as achieved through Tai Chi, that strength and relaxation are attained. Tai Chi improves the global health of the individual, uniting the physical well-being with emotional wellbeing and mental state, so it serves to improve the quality of life of the individual who practices it at all levels of life $[8,9,10]$.

\section{Aerobics}

Studies performed on the subject, show evidence which suggests that exercise, such as cycling, aquatic and strength training, may be helpful for individuals with multiple sclerosis $[11,12]$.

The contemporan consensus is that exercise does no prejudice the multiple sclerosis patients, on the contrary, aerobics may be of benefit for an individual's fitness, well-being and strength, while decreasing the intensity of their symptoms of pain and fatigue $[13,14]$. Treadmill and bicycle exercises are demonstrated to be promoters of both related practice and use of the locomotor system concerned with walking and can provide an aerobic training experience.

Physical recovery of patients with multiple sclerosis, in fact, recovery from fatigue is the main goal of this study, because fatigue is a prevalent factor among these individuals, producing negative effects on the physical, mental, but also on the emotional status.

\section{Material and method}

We recruited 100 patients with Relapsing-Remitting Multiple Sclerosis, with the Expanded Disability Status Scale (EDSS) $<3.5$.

The inclusion criteria were: a diagnosis of multiple sclerosis according to the criteria of Poser et al, a score of 3.5 or less on the Expanded Disability Status Scale (EDSS) because individuals with an EDSS score greater than 3.5 need more assistance, being less independent, and age between 20 and 50 years.

The exclusion criteria were: steroid or immunosuppressive therapy within the past 4 weeks. Patients were also excluded if their diagnosis was not clearly established, if they suffered from an acute relapse or severe cognitive deficits, or had signs of any psychiatric disease.
Another exclusion criterion was: history of cardiac, pulmonary, orthopedic, metabolic, or other medical conditions diagnosed before participation. Participants were excluded if they participated in a regular exercise program within 3 months before the study.

After applying the inclusion and exclusion criteria, 75 participants with multiple sclerosis were eligible for participating in the study.

All subjects were told about the purpose of the study and written informed consent was obtained prior to entering the study.

\section{- Neurological examination}

A neurological examination was performed using the Expanded Disability Status Scale (EDSS). The disease characteristics, clinical form, number of exacerbations, medical treatment, duration of illness and use of ambulatory aids were recorded. The Expanded Disability Status Scale scores ranged from 2.5 to 3.5 and were not statistically different from one another $(p>.05)$. The females represented $63.1 \%$ and the males represented $36.9 \%$. The age of the patients was between the interval of 27-44, with the mean of 35.72 years (std 5.14).

\section{- Training programs}

The multiple sclerosis patients were divided in three groups. Each group included 25 patients, with the correspondence of yoga training group, Tai Chi training group and aerobic training group. The three groups performed corresponding training sessions for 4 weeks, with the frequency of 3 sessions per week. The subjects of the study took part in three supervised training sessions per week, for 4 weeks. Each training session consisted of a 30min bicycle or treadmill exercise training for the aerobic group, one hour for the yoga group and one hour for the Tai Chi group.

\section{- Yoga training program}

The yoga training program consisted of 3 sessions per week, one hour per session, for 4 weeks. The yoga training program presented the following stages: warm-ups and mobilizing techniques, balance practices, developing awareness proprioception, strengthening postures adapted for the individual, work-out that helped to ease muscle spasms, gentle stretches and relaxation, 
coordination practices. The sessions begun and ended with relaxation techniques consisting of: Pratyahara, breathing and meditation and adaptive postures and preliminaries, and warm-ups. Each exercise was performed for 5-10 minutes, depending on each patient's possibility.

The Asana technique was used for:

- posture and spine;

- stability and strength;

- shoulders and upper back;

- hips and pelvis;

- balance;

- $\quad$ super stretches;

- restorative postures.

\section{- $\quad$ Tai Chi}

The Tai Chi training program consisted of 3 sessions per week, one hour per session, for 4 weeks. Warmup exercises were performed for 10-15 minutes in a Tai Chi session and soft stretching gradually gave the practitioner flexibility. Breathing exercises were also performed with the aim of increasing oxygenation and teach the practitioners to breathe properly. Tai Chi is characterized by twisting movements that reinforce tendons, joints and bone structure; it is also characterized by a constant work of muscles of the back, spine, neck and shoulders, which is useful for multiple sclerosis patients that often encounter pain caused by muscle contractures in these areas. Almost all exercises were performed standing up and their performance involved hands, fingers, arms, legs, back and head. The Tai Chi sessions for beginners consisted of exercises for opening joints, and stretching muscles and tendons to focus attention and breathing. It consisted of stretching, relaxation and breathing, sitting or stretching.

\section{- Aerobic training program}

The aerobic training program consisted of 3 sessions per week, one hour per session, for 4 weeks. The patients alternated the stationary bike with the treadmill program to prevent boredom, repetitive stress injuries and a plateau effect from using the same muscles to perform the same exercises. Both of the machines primarily focus on lower-body exercises, which are a target in multiple sclerosis patients' training. All sessions started with 10-15 minutes of easy exercises, after that, followed by a period of 15-20 minutes of cycling or treadmill, a short break, and then exercises on the other machine for 15-20 minutes. All patients were advised to exercise at their optimum speed and to avoid excess or pain.

The results of the training were tested before and after the period of 4 weeks, using the Modified Fatigue Impact Scale Test - 5-Item Version (MFIS-5). The MFIS-5 measures the impact of fatigue on the cognitive, physical and psychosocial function. The introductory statements of the test study the following aspects: the way in which fatigue impacts the physical and mental state of a person. Patients are questioned to assess one number (from a 5point Likert scoring system) that is the fitting correlation between how often fatigue has affected them during the past 4 weeks. The scale consists of the following indicatives: 'never', 'rarely', 'sometimes', 'often' and 'almost always' each scored $0-4$, respectively. The five statements are suffixed with: 'Because of my fatigue during the past 4 weeks', as follows: 'I have been less alert'; 'I have been limited in my ability to do things away from home'; 'I have had trouble maintaining physical effort for long periods'; 'I have been less able to complete tasks that require physical effort' and 'I have had trouble concentrating'. The sum of the five results of the questions shows a total score between 0 and 20. The performance of the test is advisable for clinical practice.

The results of the training were statistically obtained using the repeated measures analysis of variance that incorporated a covariate variable (ANCOVA) with the pretest results as a covariate and with time (pre vs. post) as the within subjects factor and group (yoga vs. Tai Chi vs. aerobic) entered as the between-subjects factor. A value of $p$ $<0.05$ was taken as significant. All analyses were performed using IBM SPSS Statistics 20.

\section{Results}

An ANCOVA was run to determine the effect of a yoga trial, Tai Chi trial and aerobic exercise training trial on post-intervention fatigue measurement after controlling for pre-intervention fatigue measurement. After adjustment for preintervention fatigue intervention, there was a statistically significant difference in postintervention fatigue measurement between the 
interventions, $\mathrm{F}(2,71)=6.812, \mathrm{p}<.002$, partial $\eta 2=$ .909 .

The post hoc analysis was performed with a Bonferroni adjustment.
Post-intervention fatigue measurements were statistically significantly greater in the aerobic exercise group vs. the yoga group (mean difference of 0.712 (95\% CI, 0.230 to 1.195), $\mathrm{p}<.002$ ) (Table I).

Table I. Pairwise Comparisons (Dependent Variable: POST_TEST)

\begin{tabular}{|c|c|c|c|c|c|c|}
\hline \multirow[t]{2}{*}{ (I) GROUP } & \multirow[t]{2}{*}{ (J) GROUP } & \multirow[t]{2}{*}{$\begin{array}{c}\text { Mean Difference } \\
(\mathrm{I}-\mathrm{J})\end{array}$} & \multirow[t]{2}{*}{ Std. Error } & \multirow[t]{2}{*}{ Sig.b } & \multicolumn{2}{|c|}{$\begin{array}{l}\text { 95\% Confidence Interval for } \\
\text { Difference }^{b}\end{array}$} \\
\hline & & & & & Lower Bound & Upper Bound \\
\hline \multirow{2}{*}{ YOGA GROUP } & TAI CHI GROUP &,- 232 & , 197 & ,727 &,- 715 & ,250 \\
\hline & AEROBIC GROUP &,$- 712^{*}$ & 197 & ,002 & $-1,195$ &,- 230 \\
\hline \multirow{2}{*}{ TAI CHI GROUP } & YOGA GROUP & ,232 & ,197 & ,727 &,- 250 & ,715 \\
\hline & AEROBIC GROUP &,- 480 & 197 & ,052 &,- 962 & ,002 \\
\hline \multirow{2}{*}{ AEROBIC GROUP } & YOGA GROUP &, $712^{*}$ & 197 & ,002 & ,230 & 1,195 \\
\hline & TAI CHI GROUP & ,480 & 197 & ,052 &,- 002 & ,962 \\
\hline
\end{tabular}

Based on estimated marginal means

*. The mean difference is significant at the, 05 level.

b. Adjustment for multiple comparisons: Bonferroni.

The fatigue measurement was statistically significantly greater in the aerobic group (16.81 \pm 0.13 ) compared to the yoga group (16.09 \pm 0.13$)$, a mean difference of 0.712 (95\% CI, 0.230 to 1.195 ), $\mathrm{p}$ $<.002$. (Table II).

Table II. Estimates between the groups (Dependent Variable: POST_TEST)

\begin{tabular}{ccccc}
\hline GROUP & Mean & Std. Error & \multicolumn{2}{c}{$95 \%$ Confidence Interval } \\
\cline { 4 - 5 } & & & Lower Bound & Upper Bound \\
\hline YOGA GROUP & $16,099^{a}$ &, 139 & 15,821 & 16,376 \\
\hline TAI CHI GROUP & $16,331^{a}$ &, 139 & 16,053 & 16,608 \\
\hline AEROBIC GROUP & $16,811^{a}$ &, 139 & 16,533 & 17,088 \\
\hline
\end{tabular}

a. Covariates appearing in the model are evaluated at the following values:

PRE_TEST $=17,97$.

Therefore, the yoga group obtained the lowest results at the Modified Fatigue Impact Scale Test - 5Item Version (MFIS-5), being the most efficient exercise method in lowering the fatigue in multiple sclerosis patients after the period of 4 training weeks .

Comparatively, the Tai Chi and aerobic methodsdid not show any significant difference in the effectiveness of lowering the fatigue amongst multiple sclerosis patients in a period of 4 training weeks .

\section{Discussions}

Although it was difficult for the multiple sclerosis patients to identify any specific improvements in their condition, the majority reported feeling better and generally well, and noticed a difference in their state in the days when they did not have a training session.

The studies in the literature show that multiple sclerosis patients present a beneficial change using yoga, while adapting postures with breathing and relaxation $[15,16]$.

The research results regarding yoga in multiple sclerosis have shown that yoga practice relieves fatigue. A research study of Ananda yoga that included energisation exercises, breathing exercises, and isometric contraction exercises showed important improvements in the physical state of the patients in terms of fatigability relief $[17,18,19]$.

The aim of the study was to investigate the outcomes of these yoga exercises on aspects of daily living and quality of life in patients with multiple 
sclerosis. The results of the study related to encouraging beneficial outcomes in the improvement of: balance, strength, levels of anxiety and depression, feeling of vitality, concentration and sense of wellbeing [20].

A pilot trial was conducted on multiple sclerosis patients that practiced yoga classes. The study showed that the participants were able to better walk on short distances and for longer periods of time [21, 22, 23].

Also, improvements were reported in balance while reaching backwards and in fine motor coordination. The patients' quality of life also improved in perceived mental health, concentration, bladder control, walking and vision, showinga decrease in pain and fatigue [23].

\section{Conclusion}

In the current study, we were interested in examining the association between yoga, Tai Chi and aerobic programs and fatigue, in multiple sclerosis patients.

This study shows that a short-term training program, as part offatigue related rehabilitation for multiple sclerosis patients, can increase the level of physical activity.

These results provided evidence for the association of exercise methods that can beneficially affect the level of fatigue in multiple sclerosis patients, the most effective one being yoga.

Therefore, in the future training should be part of patient rehabilitation programs. This study recommends further research with larger groups, for more accurate conclusions.

\section{References}

1. Keegan B.M., Noseworthy J.H. (2002) Multiple sclerosis, Annual Review of Medicine, 53(1), 285-302.

2. Dalgas U., Stenager E., Jakobsen J, et al. (2010). Fatigue, mood and quality of life improve in MS patients after progressive resistance training, Multiple Sclerosis, 16, 480-490.

3. Docu-Axelerad A., Stroe Z.A., Docu-Axelerad D., DocuAxelerad S. (2020). Multiple sclerosis and yoga, Archives of the Balkan Medical Union, 55(1), 154158.

4. Brown T. , Kraft G. (2005). Exercise and rehabilitation for individuals with multiple sclerosis, Physical Medicine and Rehabilitation Clinics of North America, 16, 513-555.
5. Döring A., Pfueller C.F., Paul F., Dörr J. (2012). Exercise in multiple sclerosis - an integral component of disease management. EPMA Journal, 3, 1-13.

6. Docu Axelerad A., Jurja S., Stroe A. Z., Docu Axelerad S., Docu Axelerad D. (2020). The role of physical exercise in multiple sclerosis, Ovidius University Annals, Series Physical Education and Sport / Science, Movement and Health, 20 (1), 10 - 15.

7. Ahmadi A., Nikbakh M., Arastoo A., Habibi A.H. (2010). The Effects of a yoga intervention on balance, speed and endurance of walking, fatigue and quality of life in people with multiple sclerosis, Journal of Human Kinetics, 23, 71-78.

8. Mills N., Allen J., Carey Morgan S. (2000). Does Tai Chi/Qi Gong help patients with multiple sclerosis? Journal of Bodywork and Movement Therapy, 4 (1), 39-48.

9. Azimzadeh E, Hosseini MA, Nourozi K, Davidson PM (2015). Effect of Tai Chi Chuan on balance in women with multiple sclerosis, Complementary Therapies in Clinical Practice, 21(1), 57-60.

10. Kaur D, Kaur K, Billore N, Kumar G, Singh AK. (2014). Mental Tai Chi-based exercise programme vs Tai Chi for Indian multiple sclerosis patients: A pilot study. International, Journal of Current Research and Review, 6(19), 24-30.

11. Docu Axelerad A., Docu Axelerad D., Docu Axelerad S., Stroe A. Z. (2019). Walking in Parkinson's disease, Ovidius University Annals, Series Physical Education and Sport / SCIENCE, MOVEMENT AND HEALTH, 19(2), $350-354$.

12. Stroe A. Z., Docu Axelerad S., Docu Axelerad D., Docu Axelerad A. (2019). Exercises in Parkinson's disease, Ovidius University Annals, Series Physical Education and Sport / Science, Movement and Health, 19 (2), $344-349$.

13. Docu Axelerad A., Stroe A. Z., Docu Axelerad S., Docu Axelerad D. (2019). Divinity in dementia, Proceedings DIALOGO, 6(1), 187 - 194.

14. MacAllister W.S., Krupp L.B. (2005). Multiple sclerosis-related fatigue. Physical Medicine and Rehabilitation Clinics of North America, 16, 483-502.

15. Docu Axelerad A., Stroe A. Z., Docu Axelerad S. (2019). Combating Depression in Parkinson's Disease with Melotherapy, Proceedings DIALOGO (The 10th Scholarly Meeting on the Dialogue between Science and Theology), 6(1), $195-202$.

16. Petajan JH, Gappmaier E, White AT, et al. (1996). Impact of aerobic training on fitness and quality of life in multiple sclerosis, Annals of Neurolology, 39, 432441.

17. Docu Axelerad A., Stroe A. Z., Docu Axelerad S. (2019). How religiosity affects Parkinson's disease symptoms, Proceedings DIALOGO, 6(1), 203 - 211. 
18. Dantes E., Docu Axelerad S., Stroe A. Z., Docu Axelerad D., Docu Axelerad A. (2020) The rehabilitation of hemiparesis after stroke. Ovidius University Annals, Series Physical Education and Sport / Science, Movement and Health, 20 (1), 5 - 9.

19. Romberg A., Virtanen A., Ruutiainen J., et al. (2004) Effects of a 6-month exercise program on patients with multiple sclerosis: a randomized study, Neurology, 63, 2034-2038.

20. 20. Docu Axelerad D., Docu Axelerad S., Dantes E., Stroe A. Z., Docu Axelerad A. (2020). Mixed dementia and physical exercise, Ovidius University Annals, Series Physical Education and Sport/Science, Movement and Health, 20 (1), 16 - 21.
21. Stroe A. Z., Docu Axelerad S., Docu Axelerad D., Docu Axelerad A. (2020). Neurorehabilitation through exercise in parkinson's disease patients, Ovidius University Annals, Series Physical Education and Sport /Science, Movement and Health, 20 (1), 67 71.

22. Docu Axelerad A., Docu Axelerad D. (2015). Comparative Evaluation of Pregabaline, Gabapentine, Sertraline and Duloxetine in Painful Diabetic Non Insulin-dependent Neuropathy,Procedia - Social and Behavioral Sciences, 191, 469-472.

23. Mostert S., Kesselring J. (2002). Effects of a shortterm exercise training program on aerobic fitness, fatigue, health perception and activity level of subjects with multiple sclerosis, Multiple Sclerosis, 8, 161-168. 